\section{Measuring the value of public- private partnerships in the pharmaceutical sciences}

\section{Tom. R. Denee, Arnold Sneekes, Pieter Stolk, Antoine Juliens, Jan A. M. Raaijmakers, Michel Goldman, Daan J. A. Crommelin and Jorg W. Janssen}

The declining productivity of drug research and development $(\mathrm{R} \& \mathrm{D})$ analysed in an article by Paul and colleagues (How to improve R\&D productivity: the pharmaceutical industry's grand challenge. Nature Rev. Drug Discov. 9, 203-214 (2010)) $)^{1}$ is of major concern for private and public stakeholders in the pharmaceutical industry, and in health care more broadly. One strategy to tackle this challenge that has gained momentum in recent years is the establishment of precompetitive public-private partnerships (PPPs) to focus on issues that are too large for single organizations to effectively address alone, such as the development of biomarkers of drug toxicity ${ }^{2}$. Examples of such partnerships include the Innovative Medicines Initiative in the European Union, the Biomarkers Consortium in the United States and Top Institute Pharma in the Netherlands.

Evaluating the success of PPPs is important to justify the public investments being made and to identify the best practices. However, how the value of PPPs in the pharmaceutical sector should be measured is still a relatively unexplored terrain. With this in mind, we propose a framework and list of indicators for measuring the value of PPPs in the pharmaceutical sector, based on a literature study and two international stakeholder workshops involving over 50 leaders from industry, academia, government and PPPs, in which the proposed indicators were discussed (see Supplementary information S1 (box)).

The framework resulting from these discussions, which has four stages and four domains for value creation, is shown in FIG. 1, which also includes examples of measurable indicators. The four stages are: input, process, output and outcome. For the 'input' stage, indicators measure the ability of the PPP to bring together the people, funds and knowledge needed to create the network for collaboration. For the 'process' stage, indicators measure how the different parties in the partnership work together. The remaining two stages - 'output' and 'outcome' - assess the short-term and long-term results of (projects in) a PPP, respectively, with the aim of reflecting the complexity and long timelines of pharmaceutical R\&D.

\begin{tabular}{|c|c|c|c|c|}
\hline & Input & Process & Output & Outcome \\
\hline Netv & $\begin{array}{l}\text { Number } \\
\text { and diversity } \\
\text { of partners }\end{array}$ & $\begin{array}{l}\text { Exchange of } \\
\text { information } \\
\text { between partners }\end{array}$ & $\begin{array}{l}\text { Number of } \\
\text { projects } \\
\text { continued } \\
\text { after PPP } \\
\text { funding }\end{array}$ & $\begin{array}{l}\text { Number and size of } \\
\text { new partnerships } \\
\text { inspired by PPPs }\end{array}$ \\
\hline & $\begin{array}{l}\text { Formal } \\
\text { knowledge } \\
\text { sharing; for } \\
\text { example, } \\
\text { background } \\
\text { IP in consortia }\end{array}$ & $\begin{array}{l}\text { Knowledge sharing } \\
\text { through percentage } \\
\text { of personnel } \\
\text { exchanged and } \\
\text { number of consortia } \\
\text { meetings }\end{array}$ & $\begin{array}{l}\text { Number and } \\
\text { citation score } \\
\text { for joint } \\
\text { publications }\end{array}$ & $\begin{array}{l}\text { Number of products } \\
\text { in clinical } \\
\text { development based } \\
\text { (partially) on } \\
\text { knowledge } \\
\text { genarated in PPPs }\end{array}$ \\
\hline Human capital & $\begin{array}{l}\text { Number of } \\
\text { experts involved, } \\
\text { number of } \\
\text { highly cited } \\
\text { researchers }\end{array}$ & $\begin{array}{l}\text { Percentage of } \\
\text { researchers trained } \\
\text { via PPP-specific } \\
\text { courses }\end{array}$ & $\begin{array}{l}\text { Number of } \\
\text { completed } \\
\text { PhDs and } \\
\text { postdoctoral } \\
\text { positions }\end{array}$ & $\begin{array}{l}\text { Percentage of } \\
\text { trained researchers } \\
\text { working in R\&D } \\
\text { positions in the } \\
\text { sector }\end{array}$ \\
\hline $\begin{array}{l}\text { Financials } \\
\text { and operations }\end{array}$ & $\begin{array}{l}\text { Total } \\
\text { research } \\
\text { funding } \\
\text { available in } \\
\text { partnership }\end{array}$ & $\begin{array}{l}\text { Percentage of } \\
\text { researchers and } \\
\text { staff using intranet } \\
\text { on a regular basis }\end{array}$ & $\begin{array}{l}\text { Percentage } \\
\text { of milestones } \\
\text { achieved in } \\
\text { consortia }\end{array}$ & $\begin{array}{l}\text { Return on } \\
\text { investment after } \\
5 \text { years at industrial } \\
\text { partners and } \\
\text { in start-ups }\end{array}$ \\
\hline
\end{tabular}

Figure 1 | Proposed framework for evaluating PPPs in the pharmaceutical sciences. The framework consists of four stages (shown from left to right) and four domains (shown from top to bottom). Examples of concrete and measurable indicators to assess the value of a public-private partnership (PPP) are included. IP, intellectual property; RED, research and development.

The four domains for value creation address the incentives for participation in a PPP. These domains are: 'networks' (how the publicprivate platform serves as a bridge between various stakeholders), 'know-how' (access to new techniques, proprietary knowledge and sharing of knowledge), 'human capital' (the training of a new generation of biomedical researchers) and 'financials and operations' (measuring the multipliers gained for partners, the efficiency of the PPP operations and the eventual (economic) benefits resulting from the PPP).

However, defining a set of indicators is just the first step. To fully implement performance measurement in a PPP, three conditions have to be met: first, support from all partners; second, a clearly defined method for data collection; and third, a well-equipped mediating body. Furthermore, when using such frameworks it is important to consider that value measurement should reflect the stage of maturity of the PPP. For example, given the lengthy timelines that are characteristic of the pharmaceutical industry, the emphasis for a PPP may lie on the 'input' and 'process' indicators for the first 5 years. Five years later, 'output' indicators would have a more important role, and in the long term (10 years or more) 'outcome' indicators will become relevant.

Measuring the value of PPPs in the pharmaceutical sector will remain a complex area. However, as PPPs are an increasingly important and extensively used instrument for public and private stakeholders to address the innovation crisis in pharmaceutical R\&D, objective and relevant measurements that meet the needs of all stakeholders are essential.

Tom. R. Denee is at Erasmus University Rotterdam, 3000 DR Rotterdam, The Netherlands.

Arnold Sneekes, Pieter Stolk, Daan J. A. Crommelin and Jorg W. Janssen are at Top Institute Pharma 2333 BD Leiden, The Netherlands.

Antoine Juliens and Michel Goldman are at the Innovative Medicines Initiative, 1060 Brussels, Belgium.

Jan A.M. Raaijmakers is at GlaxoSmithKline Europe, 3705 LZ Zeist, The Netherlands.

Pieter Stolk, Jan A.M. Raaijmakers and Daan J. A. Crommelin are also at the Utrecht Institute for Pharmaceutical Sciences, Utrecht University, 3508 TB, Utrecht, The Netherlands. Correspondence to J.W.J. e-mail: jorg.janssen@tipharma.com doi: 10.1038/nrd3078-c1

Published online 30 March 2012

Paul, S. M. et al. How to improve R\&D productivity: the pharmaceutical industry's grand challenge. Nature Rev. Drug Discov. 9, 203-214 (2010)

2. Tralau-Stewart, C. J., Wyatt, C. A., Kleyn, D. E. \& Ayad, A Drug discovery: new models for industry-academic partnerships. Drug Discov. Today 14, 95-101 (2009).

\section{Competing interests statement}

T.R.D. is employed by Crucell N.V., an affiliate of Johnson \& Johnson. At the time of writing the paper, he was a student at Erasmus University Rotterdam. J.A.M.R. is employed by GlaxoSmithKline and holds stocks in this company. A.S., P.S. A.J., M.G., D.J.A. and J.W.J. declare no competing financial interests. 